\title{
Perceptions of Plagiarism Among Medical and Nursing Students in Erbil, Iraq
}

Kameran H. Ismail

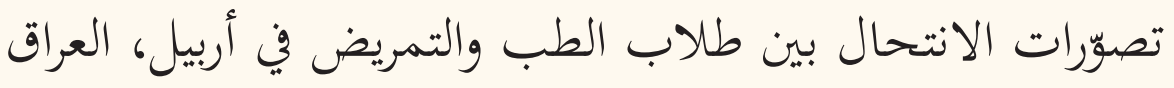

كامران حسن إسماعيل

ABSTRACT: Objectives: The rapidly rising incidence of plagiarism among students at universities throughout the world requires attention. This study aimed to determine the extent to which medical and nursing students in Erbil, Iraq, plagiarise, their knowledge, understanding and perceptions of plagiarism and the underlying factors that may lead them to plagiarise. Methods: This cross-sectional study was carried out between January and June 2017 among a sample of 400 undergraduate medical and nursing students at Hawler Medical University in Erbil. Plagiarism-related data were collected through a specially designed self-administered questionnaire. Results: In total, 280 (70\%) medical students and $120(30 \%)$ nursing students were included in the study. The reported prevalence of plagiarism was $54.3 \%$, with a slightly higher prevalence among male students compared to female students $(54.9 \%$ versus $53.8 \% ; P=0.820)$ and medical students compared to nursing students $(58.9 \%$ versus $43.3 \%$; $(P=0.004)$. Alarmingly, $34.8 \%$ of the students did not know what plagiarism was, and only $28 \%$ were aware of the legal consequences of plagiarism. Reported reasons for plagiarising included laziness and the ease with which others' work could be plagiarised, confusion, cultural reasons and pressure to meet deadlines. Conclusion: There was a lack of understanding of plagiarism and its legal ramifications among undergraduate medical and nursing students in Erbil. The findings of this study indicate that there is an urgent need to increase students' understanding of plagiarism and its consequences so as to reduce the incidence of this type of academic misconduct.

Keywords: Undergraduate Medical Education; Plagiarism; Medical Students; Nursing Students; Perceptions; Iraq.

الملخص: الهذف: التزايد العريع للانتحال بين طلاب الجامعات حول العالم يتطلب الإهتمام. تهدف هذه الدراسة إلى إلى معرفة مدىى مزاولة

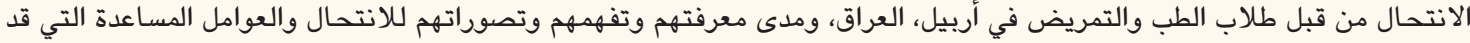

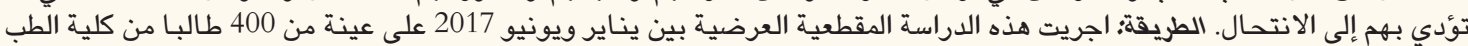

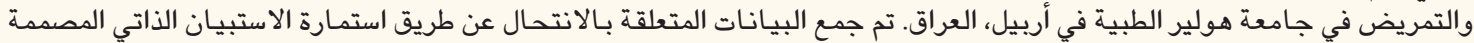

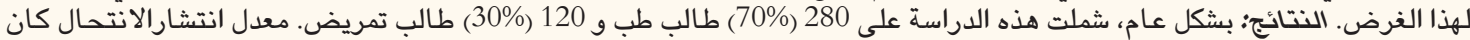

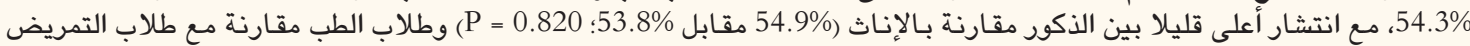

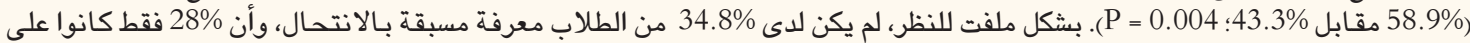

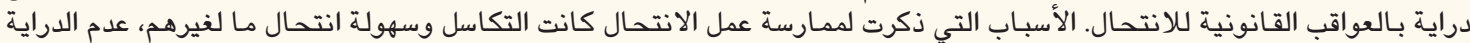

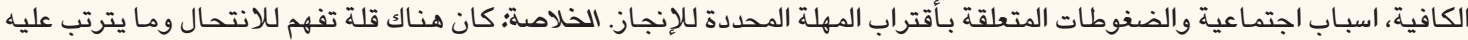

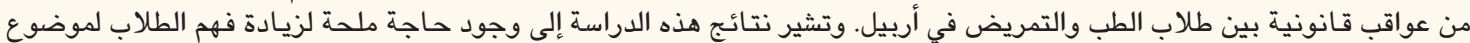

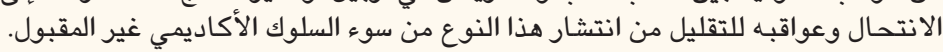

الكلمات المفتاحية: التعليم الطبي الجامعي الأولي؛ الانتحال؛ طلاب الطب؛ طلاب التمريض؛ الإدراك؛ العراق.

\section{AdVANCES IN KNOWLEDGE}

Plagiarism was found to occur frequently among undergraduate medical and nursing students in Erbil, Iraq, with a significantly greater prevalence among medical rather than nursing students.

Unfortunately, very few of the students in this study were aware of the legal consequences of plagiarism.

\section{Application to Patient Care}

Determining reasons for plagiarism among medical students is important to guide academic policies and ensure the medical education system remains fair and rigorous. This will indirectly affect patient care once the students graduate and begin to work in clinical practice.

$\mathrm{P}$ ROFESSIONAL BEHAVIOURS AND ATTITUDES are increasingly important in medical education. Unprofessional behaviours in doctors can potentially jeopardise patient safety, compromise working relationships and cause disruption and distress. ${ }^{1}$ Plagiarism constitutes the use and misrepresentation of another person's thoughts, words or ideas, without clear attribution to their original source. ${ }^{2}$ Medical students who plagiarise may graduate and become doctors, despite not necessarily having the 
requisite knowledge to competently practice medicine. ${ }^{3,4}$ The rapidly-growing prevalence of plagiarism at universities throughout the world requires attention from faculties, particularly as a lack of attention to this issue increases the risk of students plagiarising other people's work. ${ }^{2,5}$

While plagiarism is a well-known problem, its occurrence is likely overestimated by both teachers and students alike. ${ }^{6,7}$ Owunwanne et al. reported that $56 \%$ of freshmen at a business school in the USA had plagiarised some of their material. ${ }^{8}$ A recent literature review found that most studies report that $50-65 \%$ - and, in some cases, more than $70 \%$-of students have confessed to some form of cheating. ${ }^{9}$ Critically, some students do not even consider plagiarism to be cheating, seeing these as two distinct actions. ${ }^{10}$ Rennie et al. reported that $56 \%$ of medical students consulted at a Scottish university admitted that they would copy material directly from another source without using quotation marks. ${ }^{11}$

Unfortunately, plagiarism has become easier and more prevalent in recent years due to the widespread use of computers and easy access to multiple information resources via the Internet. ${ }^{3}$ In Erbil, Iraq, there is a lack of published data regarding the incidence of plagiarism among medical students or how such students perceive issues related to plagiarism. Therefore, this study was conducted to establish the self-reported prevalence, reasons for and perceptions of plagiarism among medical and nursing students at Hawler Medical University in Erbil. It is important to determine students' beliefs concerning the frequency and nature of plagiarism as such knowledge may impact how courses are designed and how cases of potential plagiarism are dealt with by academic institutions.

\section{Methods}

This cross-sectional study was carried out between January and June 2017 among a sample of 400 undergraduate students from the College of Medicine and the College of Nursing at Hawler Medical University. Data were collected using a specially-designed selfadministered questionnaire after conducting a pilot study.

Each student completed the questionnaire which collected various data variables, including the students' personal information (i.e. age, gender and field of study), knowledge about plagiarism (i.e. their awareness of what plagiarism is and its consequences), attitudes towards plagiarism (i.e. how serious the students consider plagiarism to be and whether plagiarism is a professional or ethical practice), prevalence of plagiarism (i.e. how frequently various forms of plagiarism are practised), reasons for plagiarism (i.e. why the students might wish to plagiarise) and the perceived attitude towards plagiarism on the part of their academic institution.

Data were analysed using the Statistical Package for the Social Sciences (SPSS), Version 21.0 (IBM Corp., Armonk, New York, USA). A Chi-squared test was used to compare associations between variations. The level of statistical significance was set at $P \leq 0.050$. All protocols for this study were approved by the Ethical Committee of the College of Medicine at Hawler Medical University. The relevant authorities at the College of Medicine and the College of Nursing gave permission for this study to be carried out. Verbal informed consent was obtained from all participants prior to data collection and all participation was entirely voluntary in nature.

\section{Results}

A total of 280 (70\%) medical students and 120 (30\%) nursing students were included in the study. The mean age of the sample was $21.48 \pm 0.95$ years old (range: 9-25 years), with the mean age of the medical students being $21.33 \pm 0.85$ years old (range: $19-24$ years) and the mean age of the nursing students being $21.85 \pm$ 1.08 years old (range: 20-25 years). Male students constituted $40.5 \%$ of the total sample, $46.4 \%$ of the medical students and $26.7 \%$ of the nursing students. The male-to-female ratio of the total sample was 1:1.5.

In total, $54.3 \%$ of the students reported that they practised plagiarism. There was a slightly higher although non-significant difference in the frequency of plagiarism among male students compared to female students (54.9\% versus 53.8\%; $P=0.820$ ) [Table 1 ]. However, there was a significant difference in the prevalence of plagiarism among medical students compared to nursing students (58.9\% versus $43.3 \%$; $P=0.004)$. Most of the students reported that they plagiarised by copying and pasting (81.1\%); this practice was significantly more frequent among nursing rather than medical students (92.3\% versus $77.6 \% ; P=0.018$ ).

Table 1: Prevalence of plagiarism according to gender among medical and nursing students at Hawler Medical University, Erbil, Iraq ( $\mathrm{N}=400)$

\begin{tabular}{|c|c|c|c|c|}
\hline & \multicolumn{3}{|c|}{ n (\%) } & \multirow{2}{*}{$\begin{array}{c}P \\
\text { value }\end{array}$} \\
\hline & $\begin{array}{c}\text { Male } \\
\text { students } \\
(\mathrm{n}=162)\end{array}$ & $\begin{array}{c}\text { Female } \\
\text { students } \\
(\mathrm{n}=238)\end{array}$ & Total & \\
\hline Practised & $\begin{array}{c}89 \\
(54.9)\end{array}$ & $\begin{array}{c}128 \\
(53.8)\end{array}$ & $\begin{array}{c}217 \\
(54.3)\end{array}$ & \multirow{2}{*}{0.820} \\
\hline Not practised & $\begin{array}{c}73 \\
(45.1)\end{array}$ & $\begin{array}{c}110 \\
(46.2)\end{array}$ & $\begin{array}{c}183 \\
(45.8)\end{array}$ & \\
\hline
\end{tabular}


Table 2: Prevalence, types and reasons for plagiarism among medical and nursing students at Hawler Medical University, Erbil, Iraq ( $\mathrm{N}=400)$

$\begin{array}{llll} & \text { n (\%) } & & \begin{array}{c}P \\ \text { value }\end{array} \\ \begin{array}{lll}\text { Medical } \\ \text { students }\end{array} & \begin{array}{l}\text { Nursing } \\ \text { students } \\ (\mathbf{n}=280)\end{array} & \text { Total } & \\ & (\mathbf{n}=120) & & \end{array}$

Prevalence of plagiarism

$\begin{array}{lcccc}\text { Practised } & 165 & 52 & 217 & \\ & (58.9) & (43.3) & (54.3) & \\ & & & & 0.004 \\ \text { Not practised } & 115 & 68 & 183 & \end{array}$

Type of plagiarism practised*

Copy and paste

$\begin{array}{lll}128 & 48 & 176\end{array}$

Copy from peers

$37 \quad 4 \quad 41$

$(22.4) \quad(7.7) \quad(18.9)$

Reasons for plagiarism

$\begin{array}{lccc}\begin{array}{l}\text { Ease of } \\ \text { plagiarising/ } \\ \text { laziness }\end{array} & 142 & 44 & 186 \\ \begin{array}{l}\text { Pressure to meet } \\ \text { deadlines }\end{array} & 59 & (36.7) & (46.5) \\ & (21.1) & (25) & (22.3) \\ \text { Confusion } & 39 & 21 & 60 \\ & (13.9) & (17.5) & (15) \\ \text { Cultural reasons } & 40 & 25 & 65 \\ & (14.3) & (20.8) & (16.3)\end{array}$

"Among those students who admitted to having practised plagiarism.

Table 3: Knowledge of plagiarism among medical and nursing students at Hawler Medical University, Erbil, Iraq $(\mathrm{N}=400)$

$\begin{array}{llll} & \text { n (\%) } & & P \text { value } \\ \begin{array}{l}\text { Medical } \\ \text { students } \\ (\mathrm{n}=280)\end{array} & \begin{array}{l}\text { Nursing } \\ \text { students } \\ (\mathrm{n}=120)\end{array} & \text { Total } & \\ \end{array}$

Do you know what plagiarism is?

$\begin{array}{cccc}\text { Yes } & 189 & 72 & 261 \\ & (67.5) & (60) & (65.3) \\ \text { No } & 91 & 48 & 139 \\ & (32.5) & (40) & (34.8)\end{array}$

0.149

Are you aware of the legal consequences of plagiarism?

$\begin{array}{cccc}\text { Yes } & 76 & 36 & 112 \\ & (27.1) & (30) & (28) \\ \text { No } & 204 & 84 & 288 \\ & (72.9) & (70) & (72)\end{array}$

Do you consider plagiarism to be unprofessional or unethical?

$\begin{array}{cccc}\text { Yes } & 225 & 93 & 318 \\ & (80.4) & (77.5) & (79.5) \\ \text { No } & 55 & 27 & 82 \\ & (19.6) & (22.5) & (20.5)\end{array}$

0.517
Table 4: Perceived academic detection of and response to plagiarism among medical and nursing students at Hawler Medical University, Erbil, Iraq $(\mathrm{N}=400)$

$\begin{array}{llllr}\begin{array}{l}\text { Academic } \\ \text { institution }\end{array} & & \mathbf{n}(\%) & & \begin{array}{c}P \\ \text { value }\end{array} \\ & \begin{array}{l}\text { Medical } \\ \text { students } \\ (\mathrm{n}=280)\end{array} & \begin{array}{l}\text { Nursing } \\ \text { students } \\ (\mathrm{n}=120)\end{array} & \text { Total } & \\ & & & \end{array}$

Successful detection of plagiarism

Yes

$85 \quad 70 \quad 155$

(30.4) (58.3) (38.8)

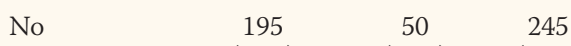

$<0.001$

Response to plagiarism

\begin{tabular}{|c|c|c|}
\hline $\begin{array}{l}\text { Report to } \\
\text { higher } \\
\text { authorities }\end{array}$ & $\begin{array}{c}24 \\
(8.6)\end{array}$ & $\begin{array}{c}37 \\
(30.8)\end{array}$ \\
\hline Lower grades & $\begin{array}{c}91 \\
(32.5)\end{array}$ & $\begin{array}{c}25 \\
(20.8)\end{array}$ \\
\hline Warn & $\begin{array}{c}72 \\
(25.7)\end{array}$ & $\begin{array}{c}32 \\
(26.7)\end{array}$ \\
\hline Ignore & $\begin{array}{c}93 \\
(33.2)\end{array}$ & $\begin{array}{c}26 \\
(21.7)\end{array}$ \\
\hline
\end{tabular}

Ease and laziness were the most common reason for practising plagiarism among $46.5 \%$ of the sample, while the least common reason was confusion (15\%) [Table 2].

Nearly two-thirds (65.3\%) of the sample knew what plagiarism was. While medical students more frequently knew what plagiarism was in comparison to nursing students, this difference was not statistically significant $(67.5 \%$ versus $60 \% ; P=0.149)$. However, only $28 \%$ of the students were aware of the legal penalties for practising plagiarism. Plagiarism was considered unprofessional and unethical by the majority of students (79.5\%), with no statistically significant difference according to field of study $(P=0.517)$ [Table 3]. Of the 261 students who knew the definition of plagiarism, 59.4\% practised plagiarism, with a statistically significant association between plagiarising and knowledge of plagiarism $(P=0.005)$. Of the 112 students who were aware of the legal consequences of plagiarism, 57.1\% plagiarised; however, there was no statistically significant association between plagiarising and awareness of the legal consequences of plagiarism $(P=0.469)$.

A total of $61.3 \%$ of students believed that their academic institutions were not successful at detecting plagiarism. This rate was significantly higher among medical students compared to nursing students (69.6\% versus $41.7 \%$; $P<0.001)$. Medical students most frequently reported that teachers ignored plagiarism 
(33.2\%), while the most frequent reaction according to nursing students was to have the incident reported to the higher authorities (30.8\%). There was a statistically significant association between medical and nursing students with regards to the perceived response to plagiarism on the part of the academic institutions $(P<0.001)$ [Table 4].

\section{Discussion}

After their graduation, medical and nursing students become actively involved in patient care. Unfortunately, participating in acts of plagiarism as a medical student may negatively affect their medical knowledge and clinical skills, resulting in potentially unskilled physicians entering the workforce. ${ }^{12,13}$ Moreover, the incidence of plagiarism among nursing students has become more frequent in recent years, which is alarming in light of the need for integrity in this profession. ${ }^{14-16}$ The current study aimed to evaluate the frequency and perceptions of plagiarism among a sample of medical and nursing students and identify factors that may lead such students to plagiarise. To the best of the author's knowledge, this is the first such study to take place in Erbil.

In the current study, more than half of the students were found to have practised plagiarism. The average percentage of plagiarised text in essays written by medical students in Croatia was found to be $19 \% .{ }^{17}$ Another study revealed that the proportion of American undergraduate students who had cheated during written assignments ranged from 3-38\%. ${ }^{18}$ In a review of literature, Kusnoor et al. found that the frequency of various cheating behaviours among medical students in the USA was $4.7-87.6 \% .^{12}$ In a UK-based study, $61.9 \%$ of undergraduate students admitted to having plagiarised from online sources. ${ }^{19}$ In the current study, $54.3 \%$ of students reported to having practised plagiarism. This high percentage may be due to several factors, including a failure to detect plagiarism on the part of the academic institution or a lack of awareness of the legal consequences of plagiarism on the part of the students. Additionally, non-native English-speakers may plagiarise material due to their lack of proficiency in the English language. ${ }^{20}$ Other reasons for variations in reported rates of plagiarism may be due to differences in study methodologies, the criteria for plagiarism and the specific rules and regulations of academic institutions.
Despite the slightly higher incidence of plagiarism among male students in the current study, no significant association was noted between plagiarism and gender. This finding is in agreement with those of a previous study conducted in Croatia. ${ }^{17}$ Other research has indicated that male students who plagiarise have a significantly more positive attitude towards plagiarism than female students. ${ }^{21}$ Most students in the present study stated that copying and pasting was the most common method of plagiarism; similar findings were reported in Saudi Arabia, with $42 \%$ of students admittedly copying material from electronic sources without appropriate citations. ${ }^{22}$ These findings are likely due to the fact that this method of plagiarism does not require much effort. Critically, about one-third of the students in the present study did not know what plagiarism was; moreover, the vast majority were not aware of the legal penalties for practising plagiarism. In a study conducted in Pakistan, 94\% of participants were not aware of the penalties for plagiarism in place at their academic institutions. ${ }^{23}$ A newspaper article revealed that $81 \%$ and $67 \%$ of Nigerian students attending two universities in the UK and $40 \%$ of students attending Nigerian universities demonstrated a lack of awareness regarding plagiarism. ${ }^{24}$ This variation is likely due to differences in the curriculum whereby some students are taught about plagiarism much sooner than others.

In the current study, students reported the main reason for plagiarism to be laziness and the ease of plagiarising other's work, followed by the pressure to meet deadlines, cultural reasons and confusion about the topic or how to do research. Students may not know how to integrate the ideas of others and document the sources of those ideas appropriately in their texts or how to take careful and through notes during research activities. In addition, plagiarism among university students might be due to the effects of a shared cultural framework which values social impressions more than academic honesty. ${ }^{25}$ In such cases, students may plagiarise because they fear failing or are reluctant to risk submitting their own work. In addition, insufficient time between deadlines and social or family demands may result in students not having enough time to finish their assignments, thereby encouraging them to resort to plagiarism. ${ }^{26}$ In a study conducted in South Africa, laziness and poor time management were identified together to be the most common reason for plagiarism, followed by a desire for better grades, lack of understanding of the 
assignment, a lack of understanding of plagiarism and poor writing and referencing skills. ${ }^{27}$ The implications of these findings should be taken into consideration in association with social norms..$^{26,28,29}$

Ultimately, believing that others plagiarise may make students more likely to practise plagiarism themselves. If students estimate the incidence of plagiarism among their peers to be relatively high, they may consider plagiarising to be the norm and therefore less serious an offence. Thus it is important for students to be given accurate information about the incidence, nature and consequences of plagiarism, including the definition and different types of plagiarism, how to prevent plagiarism and the penalties for plagiarising. Such information can be imparted through lectures, seminars and workshops. Moreover, educational institutions should create an environment where ethical behaviour is clearly valued, which will consequently make students less likely to plagiarise. In the current study, most participants reported that the response of their academic institution in most cases of plagiarism was to either ignore the issue completely or lower the transgressor's grade; in contrast, reporting the act of plagiarism to the higher authorities was the least common response. Higher education institutions should clearly state the procedures to be followed in cases of academic dishonesty, such as plagiarism. For example, the minimum penalty for plagiarism at certain universities in the USA and UK is a lower grade for the assignment, although the student may also fail the entire course or even be expelled, depending on the severity of the case..$^{30,31}$

At Hawler Medical University, the majority of students in the current study reported that they believed most cases of plagiarism went undetected by the institution. As such, more accurate methods are needed to detect plagiarised material. Computerised plagiarism detection software such as Turnitin ${ }^{\circledR}$ (iParadigms LLC, Oakland, California, USA) and iThenticate ${ }^{\circledR}$ (iParadigms LLC) can be used to highlight plagiarised portions of student work and thus prevent or reduce the overall incidence of plagiarism. Academic institutions should make an effort to obtain licenses for such text-matching software and also provide guidelines for teachers so that these tools can be utilised appropriately. In conjunction, students should receive necessary training and support regarding how to conduct appropriate research, search for and cite high-quality sources, prevent plagiarism and improve their writing techniques. ${ }^{32}$ Overall, reducing plagiarism and creating an ethical educational environment will result in the students developing better learning, research and writing skills. These findings may potentially help guide academic policies at Hawler
Medical University and hopefully serve to lower the incidence of academic dishonesty.

This study was subject to certain limitations. Due to the lack of previous studies conducted on this topic in Erbil, the author was unable to compare the findings of the current study with that of similar research in this region. Similarly, the author was unable to benefit from other researchers' experiences when designing the questionnaire. In addition, the current study included only undergraduate students. Future research should seek to determine the frequency and perceptions of plagiarism among postgraduate students and lecturers as well as evaluate the effectiveness of anti-plagiarism interventions and prevention strategies.

\section{Conclusion}

This study found that undergraduate medical and nursing students in Erbil lacked understanding of plagiarism and its legal consequences. There is a need for effective policies and procedures to be implemented to increase students' awareness of plagiarism, thereby reducing the incidence of this form of academic dishonesty. This may necessitate the installation of specific text-matching software or a review of the academic penalties to be enforced in cases of plagiarism.

\section{CONFLICT OF INTEREST}

The author declares no conflicts of interest.

\section{FUNDING}

No funding was received for this study.

\section{References}

1. Yates J. “Concerns" about medical students' adverse behaviour and attitude: An audit of practice at Nottingham, with mapping to GMC guidance. BMC Med Educ 2014; 14:196. doi: 10.1186/ 1472-6920-14-196.

2. Mason PR. Plagiarism in scientific publications. J Infect Dev Ctries 2009; 3:1-4. doi: 10.3855/jidc.98.

3. DeVoss D, Rosati AC. "It wasn't me, was it?" Plagiarism and the web. Comput Compos 2002; 19:191-203. doi: 10.1016/S87554615(02)00112-3

4. Cole AF. Plagiarism in graduate medical education. Fam Med 2007; 39:436-8

5. Amiri F, Razmjoo SA. On Iranian EFL undergraduate students' perceptions of plagiarism. J Acad Ethics 2016; 14:115-31. doi: 10.1007/s10805-015-9245-3.

6. Hard SF, Conway JM, Moran AC. Faculty and college student beliefs about the frequency of student academic misconduct. J High Educ 2006; 77:1058-80. doi: 10.1080/00 221546.2006.11778956.

7. Engler JN, Landau JD, Epstein M. Keeping up with the Joneses: Students' perceptions of academically dishonest behaviour. Teach Psychol 2008; 35:99-102. doi: 10.1080/00986280801978418. 
8. Owunwanne D, Rustagi N, Dada R. Students' perceptions of cheating and plagiarism in higher institutions. J Coll Teach Learn 2010; 7:59-68. doi: 10.19030/tlc.v7i11.253.

9. Lambert EG, Hogan NL, Barton SM. Collegiate academic dishonesty revisited: What have they done, how often have they done it, who does it, and why did they do it? Electron J Sociol 2003; 7:1-27.

10. Bruwelheide JH. Plagiarism: Trends, thoughts, suggestions TechTrends 2010; 54:22-4. doi: 10.1007/s11528-010-0433-0.

11. Rennie SC, Crosby JR. Are “tomorrow's doctors" honest? Questionnaire study exploring medical students' attitudes and reported behaviour on academic misconduct. BMJ 2001; 322:274-5. doi: $10.1136 / \mathrm{bmj} .322 .7281 .274$.

12. Kusnoor AV, Falik R. Cheating in medical school: The unacknowledged ailment. South Med J 2013; 106:479-83. doi: 10.10 97/SMJ.0b013e3182a14388.

13. Mortaz Hejri S, Zendehdel K, Asghari F, Fotouhi A, Rashidian A. Academic disintegrity among medical students: A randomised response technique study. Med Educ 2013; 47:144-53. doi: 10. 1111/medu.12085.

14. Johnson JA. Does academic dishonesty result in unethical professional practice? J Nurses Prof Dev 2013; 29:271-3. doi: 10.1097/01.NND.0000433151.26007.f9.

15. Krueger L. Academic dishonesty among nursing students. J Nurs Educ 2014; 53:77-87. doi: 10.3928/01484834-20140122-06.

16. Macale L, Ghezzi V, Rocco G, Fida R, Vellone E, Alvaro R. Academic dishonesty among Italian nursing students: A longitudinal study. Nurse Educ Today 2017; 50:57-61. doi: 10.1016/j. nedt.2016.12.013.

17. Bilić-Zulle L, Frković V, Turk T, Azman J, Petrovecki M. Prevalence of plagiarism among medical students. Croat Med J 2005; 46:126-31.

18. McCabe DL. Cheating among college and university students: A North American perspective. Int J Educ Integr 2005; 1:1-11. doi: 10.21913/IJEI.v1i1.14.

19. Selwyn N. 'Not necessarily a bad thing...': A study of online plagiarism amongst undergraduate students. Assess Eval High Educ 2008; 33:465-79. doi: 10.1080/02602930701563104.
20. Sri Kantha S. Nobel Prize winners for literature as palliative for scientific English. Croat Med J 2003; 44:20-3.

21. Jereb E, Urh M, Jerebic J, Šprajc P. Gender differences and the awareness of plagiarism in higher education. Soc Psychol Educ 2018; 21:409-26. doi: 10.1007/s11218-017-9421-y.

22. Razek N. Academic integrity: A Saudi student perspective. Acad Educ Leadersh J 2014; 143-54.

23. Murtaza G, Zafar S, Bashir I, Hussain I. Evaluation of student's perception and behavior towards plagiarism in Pakistani universities. Acta Bioeth 2013; 19:125-30. doi: 10.4067/S1726-569X 2013000100013

24. Orim SM. Student plagiarism: do we care? Available at: www.universityworldnews.com/article.php?story $=2015060$ 9151735677 Accessed: Mar 2018.

25. Wowra SA. Moral identities, social anxiety, and academic dishonesty among American college students. Ethics Behav 2007; 17:303-21. doi: 10.1080/10508420701519312.

26. Park C. In other (people's) words: Plagiarism by university students - literature and lessons. Assess Eval High Educ 2003; 28:471-88. doi: 10.1080/02602930301677.

27. Sentleng MP, King L. Plagiarism among undergraduate students in the Faculty of Applied Science at a South African higher education institution. S Afr J Libr Inf Sci 2012; 78:57-67. doi: 10. 7553/78-1-47.

28. McCabe DL, Trevino LK, Butterfield KD. Cheating in academic institutions: A decade of research. Ethics Behav 2001; 11:219-32. doi: 10.1207/S15327019EB1103_2.

29. Rettinger DA, Kramer Y. Situational and personal causes of student cheating. Res High Educ 2009; 50:293-313. doi: 10.10 07/s11162-008-9116-5.

30. Colorado State University. Penalties for plagiarism and your legal rights. Available at: https://writing.colostate.edu/guides/ page.cfm?pageid=317\&guideid=17 Accessed: Mar 2018 .

31. University of Bradford. Penalties for plagiarism. Available at: www.brad.ac.uk/library/help/plagiarism/penalties-for-plagia rism/ Accessed: Mar 2018.

32. Smedley A, Crawford T, Cloete L. An intervention aimed at reducing plagiarism in undergraduate nursing students. Nurse Educ Pract 2015; 15:168-73. doi: 10.1016/j.nepr.2014.12.003. 